\title{
DIETHYL DITHIOLISOPHTHALATE (ETIP or 'Etisul') IN THE TREATMENT OF LEPROSY
}

\author{
A SECOND PROGRESS REPORT \\ T. F. DAVEY, O.B.E., M.D., M.SC. \\ Leprosy Service Research Unit, Uzuakoli, E. Nigeria
}

\section{Introduction}

The early stages of a pilot trial of 'Etisul' in the treatment of leprosy were described in a progress report published at the beginning of this year (Davey and Hogerzeil, 1959). At that point experience justified the following observations.

1. No signs of toxicity were found in the 65 patients taking part in the trial.

2. Administered on its own, Etisul was found to possess chemotherapeutic action which was variable, but in some patients was very marked.

3. Its activity was shortlived, most evident during the first two or three months of treatment. When administered for longer periods, evidence of drug resistance appeared, particularly in patients who through inadequate inunction had received a low dosage.

4. When standard oral chemotherapy was initiated after a short course of Etisul, progress continued to be better than average.

The close observation of the patients concerned has continued. In addition, particular attention has been given to the use of Etisul in combination with oral chemotherapy, both early and late in the course of treatment. Here it is proposed to report on the following.

A. The continued progress of patients on oral chemotherapy following shorter and longer courses of Etisul.

B. The effect of a short course of Etisul late in oral chemotherapy with DDS.

C. The progress during the first six months of patients receiving Etisul in combination with DDS.

D. The progress during the first four months of patients receiving Etisul in combination with DDS and Ciba 1906.

\section{Mode of Administration}

The reader is referred to the earlier report for a short review of the properties of ETIP. The drug is presented in 'Etisul' in the form of a perfumed $75 \%$ cream, which we have administered by inunction in a dose of 3-6 ccs. twice weekly. Poor results in the earlier stages of the trial following light and localised inunction led to the routine use of widespread inunction with good massage, using a dose of 6 ccs. twice weekly in adults. Inunction is followed by a rest for 2-3 
hours, after which the patient takes a warm bath, using scented soap. This routine has proved entirely acceptable.

\section{Toxicity}

133 patients have now received courses of Etisul, and no evidence of any toxic action has been found. Dermatitis has not been encountered. Frequent examinations of blood and urine have shown no abnormality. There has been no gastro-intestinal upset. Euphoria has been usual, doubtless due in part to the psychological stimulus supplied by inuncting an unknown substance, but in many patients also indicating a genuine sense of well-being based on real improvement in their physical condition.

\section{Assessment of progress}

In the pilot trial of new drugs, it has been our practice to assess progress on a basis of clinical, histological, and bacteriological changes. Of these the third is the least subject to fallacy, and can yield valuable information during a relatively short period of trial. This gives it particular importance in the present trial, in which we are concerned with progress in terms of weeks rather than of months or years. In considering the bacteriological picture, based always on multiple smears, two aspects are important. (a) Changes in bacterial index, and (b) Changes in bacterial morphology.

By Bacterial Index we mean the average of the findings on a single occasion at 10 sites including both ear lobes and nostrils, at each of which the concentration of bacilli is reckoned from 0 to a maximum of 4 plus, very scanty bacilli being counted as 0.5 and 4 plus indicating a smear with innumerable bacilli in every field. The Bacterial Index is at best an estimate, but experience proves its value. It is in any case a conservative basis for assessment, for a 4 plus reading will be found equally from sites at which lepromatous infiltration is still moderate and those where the skin is saturated with it, so that a marked reduction in the concentration of bacilli will have taken place in advanced cases before any change is discernable under the microscope.

Too little attention has as yet been given to the degenerative changes in bacterial morphology which take place during chemotherapy. Although in reactive states and in borderline leprosy a proportion of the bacilli in routine smears may be abnormal in shape or in staining properties, this does not alter the fact that during successful chemotherapy a progressive decline invariably takes place in the proportion of bacilli of normal shape and staining properties in routine smears. This change occurs early, and may be pronounced before any decline occurs in the Bacterial Index. The proportion of bacilli showing degenerative changes can often actually be counted, and this affords the most precise method of 
observing short term changes in the situation as far as the bacilli are concerned. We have made use of it in this work, and can give with some accuracy the time taken in any patient for the proportion of normal bacilli to fall by $50 \%$ and by $100 \%$.

The entire bacteriological findings here reported have been assessed by one specialist technician, who, unaware of the details of treatment, has lacked any bias that may inevitably have coloured the judgement of the clinician.

For control purposes we have used the standard graphs of decline in Bacterial Index which have been developed at this unit, and provide a form of control which is least open to objection. The detailed observation of morphological changes is a comparatively recent development, and records of DDS treatment during the past 10 years do not give sufficient detail to provide the reliable standard now called for where this aspect is concerned. Those covering the trial of Ciba 1906 do, however, provide a valuable basis for comparison. As we have found Ciba 1906 more speedily effective than DDS in the early stages of treatment, it is most unlikely that DDS would induce morphological changes more rapidly than did Ciba 1906.

It is worth emphasising that the principles of random selection have been applied in this work, patients being attached to the trial strictly in order of admission.

We now consider the progress of the four groups of patients.

\section{A. The continued progress of patients on oral chemotherapy following} shorter or longer courses of Etisul.

(a) Short course of Etisul.

The original pilot trial group of nine lepromatous and nine tuberculoid cases received approximately three months of inunction with ETIP (non-perfumed) in a dose of 3 ccs. twice weekly. This was followed by standard oral chemotherapy, 4 patients receiving the two drugs together for the second three months. The group has now been observed for 18 months. The last six months have done nothing to alter the impression previously gained that in these patients acceleration of the expected effect of oral chemotherapy had taken place as a result of the Etisul course.

A later group (Group 3) of ten lepromatous and five nonlepromatous cases received Etisul in a dose of 6 ccs. twice weekly for 10-12 weeks, and then continued with standard DDS therapy. They included some very severe lepromatous cases. This group has now been observed for nine months. Clinically and histologically their progress has been very satisfactory, the resolution of lepromatous infiltration being uniformly evident, accompanied by a pronounced sense of well-being. No complications have been witnessed, apart from mild and brief reactive phases in two patients. 


\section{Bacterial Index}

The average decline in Bacterial Index for the two groups is given in Figure 1. It will be observed that in both cases a rapid initial decline took place, most marked during the first two months. This was succeeded by a period of diminished progress. In the second group this persisted for three months, i.e. during the period when the dosage of DDS was being built up to its standard maintenance dose, progress then being resumed, so that at nine months it is still well in advance of what would have been expected using DDS alone. This phase of slower progress during the second three months was not so obvious in the first group, four of whom received combined treatment during this period.

\section{Morphology of Bacilli in Routine Smears}

The time taken in months for the proportion of normal bacilli in routine smears to fall by $50 \%$ and $100 \%$ from the figure at the onset is given in Table 1 .

\section{TABLE 1}

\section{Decline in proportion of normally staining bacilli}

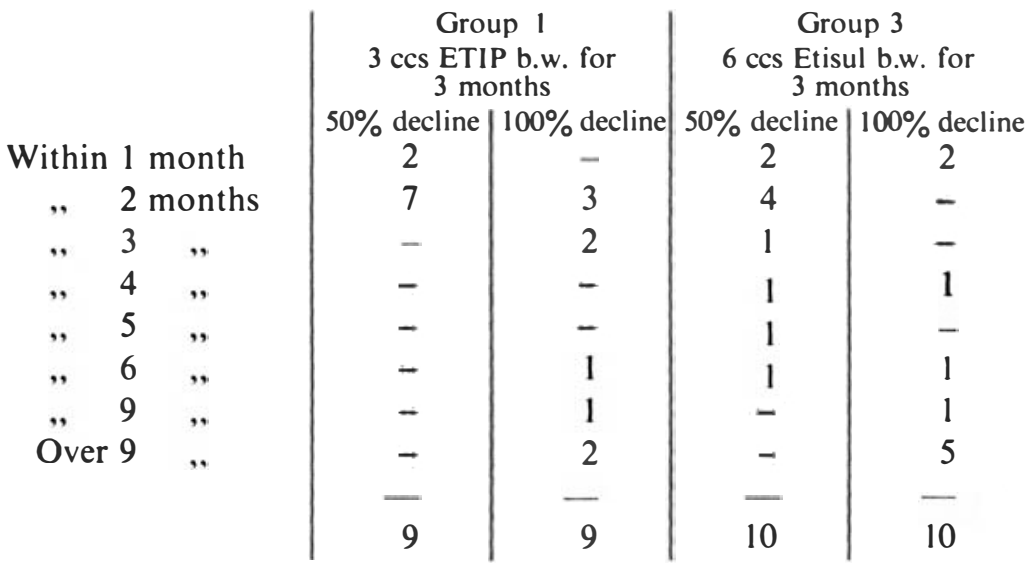

The most significant point here is that in $100 \%$ of Group 1 (milder cases) and $70 \%$ of Group 3 (more severe cases) a decline in the proportion of normal bacilli by $50 \%$ occurred during the first three months, when Etisul was being used alone.

(b) Longer course of Etisul.

A brief reference only is called for in regard to the group of 14 lepromatous and 8 tuberculoid cases (Group 2) who received from three to six months of Etisul treatment, using light inunction over a limited area of the body, with inadequate absorption, i.e. low dosage for a long period. It was in this group that evidence 
FIG 1. Decline in Bacterial Index during chemotherapy

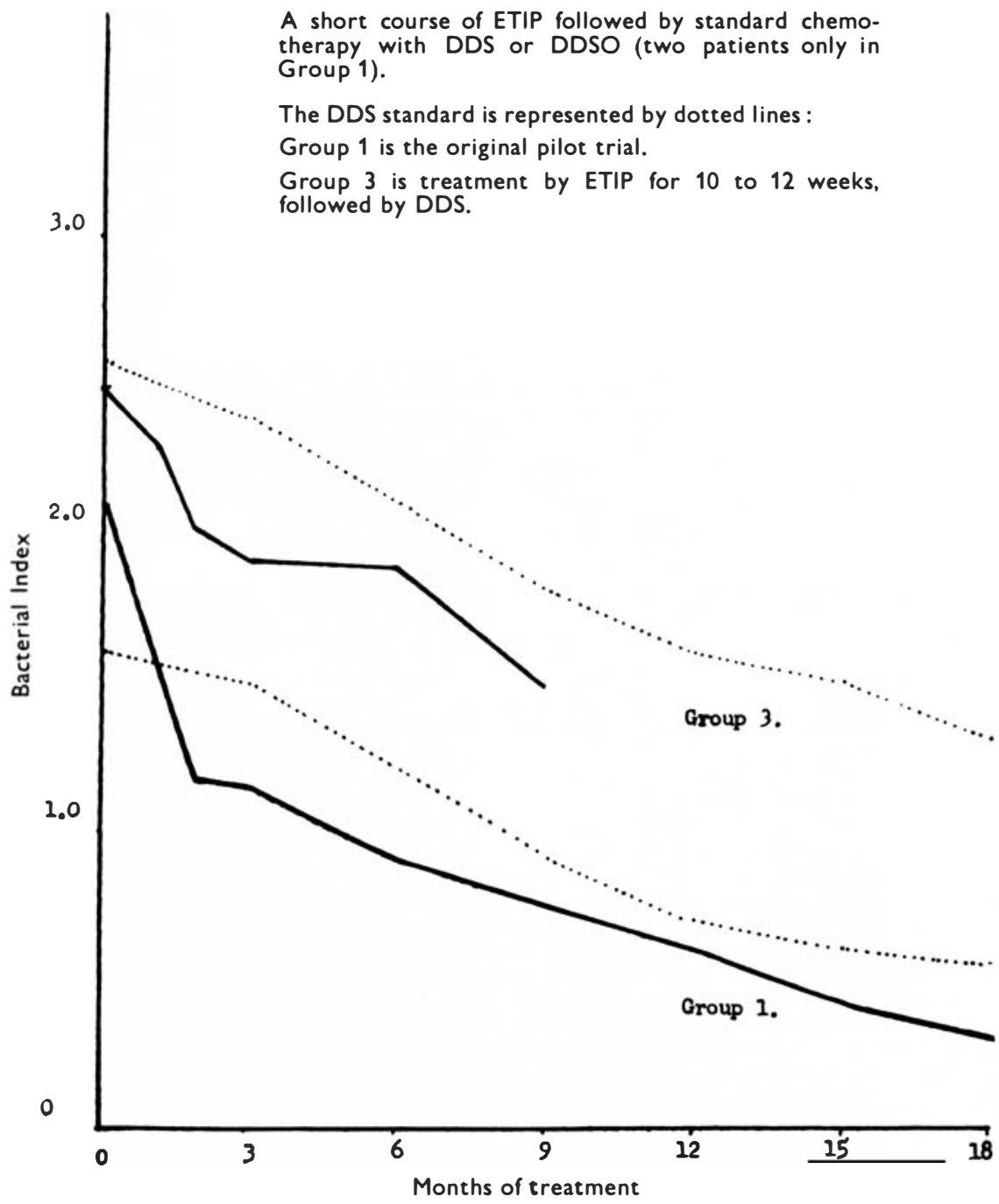

FIG. 1 
of drug resistance was encountered. When transferring the patients concerned to oral chemotherapy it was considered appropriate to give them the drug with speediest action and least toxicity known to us, namely Ciba 1906. This was given immediately in full dosage.

With an average Bacterial Index of 3.0 it is evident that the group included a high proportion of severe cases, but their progress, while good in five cases, was on the whole decidedly inferior to that of the two groups already described, as judged both by the rate of decline in Bacterial Index during Etisul treatment and also by the time taken for a decline by $50 \%$ in normal bacilli.

Continuing treatment with Ciba 1906 proved satisfactory but not outstanding. Its lack of toxicity was an obvious virtue, but bacteriological progress was not appreciably better than would have been expected with DDS during the same period, and in one or two patients was not as good. It is possible that the chemical relationship between Ciba 1906 and Etisul is sufficiently close to have affected to some extent the usefulness of Ciba 1906 in cases beginning to develop drug resistance to Etisul.

Experience with this group stresses the importance of adequate inunction in treatment with Etisul.

This earlier work led to three new groups of patients, the progress of whom is now reported for the first time.

B. The effect of a short course of Etisul late in oral chemotherapy.

A course of Etisul lasting two months was given to 15 lepromatous cases who displayed persistently positive bacteriological findings after three or four years of DDS treatment.

In two cases smears became negative within three months, but in the remainder no effects could be observed as a result of the course of Etisul other than those of a subjective nature. In all these patients the bacilli were in a granular condition. The mechanical effect of inunction and massage may very well have stimulated absorption of bacillary material, but there was no evidence that Etisul had any chemotherapeutic effect in these cases.

At the same time, a course of Etisul was given to five patients of similar type after two years of treatment with Ciba 1906. The drug had no observable effect.

Etisul is thus of interest only in the early stages of treatment. The temporary check in bacteriological improvement observed when Etisul treatment is followed by oral chemotherapy suggested its trial in combination with DDS, and during the past six months attention has been concentrated on this.

\section{Etisul in combination with DDS. Progress during the first six months.}

Twenty-four lepromatous cases are taking part in this trial. 
They have been divided into two groups. (a) In ten previously untreated patients the two drugs were administered together from the start, so that they received Etisul during the period when the maintenance dose of DDS was being built up. (b) In the remaining 14 patients DDS treatment was either initiated by us and Etisul added when the dose of DDS had reached $400 \mathrm{mg}$. weekly, or else the patient had received a short course of DDS privately before consulting us. At first a short course of Etisul was visualised in each group, but the importance of determining the influence of combined treatment on drug resistance led to the continuance of Etisul treatment beyond the three months originally envisaged. In most cases it has been continued throughout the period of trial.

Clinically, the progress of patients in both groups has been eminently satisfactory, with steady and rapid improvement without any complications. In several cases repeated biopsies have also shown well marked resolution histologically. In both these respects there is so far nothing to choose between the two groups. Their bacteriological progress will be considered separately.

\section{Group (a) Etisul and DDS starting concurrently.}

The ten patients in this group had had no previous chemotherapy, their statements in this respect being supported by bacteriological findings, repeated where thought desirable after an interval of a few weeks during which no treatment was given. Details of their bacteriological progress once treatment was initiated are given in Table 2.

TABLE 2

\section{Bacteriological status of patients receiving Etisul and DDS concurrently}

Bacterial Index

$\begin{array}{ccccccccc} & 0 & 1 & 2 & 3 & 4 & 5 & 6 & 7 \\ \text { A.O. } & 1.7 & 0.9 & 1.1 & 1.0 & 1.6 & 1.6 & 1.1 & 0.6 \\ \text { N. } & 3.5 & 3.5 & 3.1 & 3.1 & 2.9 & 2.5 & 2.1 & 1.8 \\ \text { O.A. } & 0.6 & 0.3 & 0.3 & 0.1 & 0.2 & 0.2 & 0 & 0 \\ \text { N.A. } & 2.9 & 2.8 & 2.5 & 2.4 & 2.3 & 2.5 & 1.4 & \\ \text { O.M. } & 0.3 & 0.2 & 0.1 & 0 & 0 & 0 & 0 & \\ \text { E.A. } & 1.6 & 1.5 & 1.5 & 0.7 & 1.2 & 0.5 & & \\ \text { D.O. } & 2.2 & 2.2 & 1.4 & 1.3 & 1.4 & 1.1 & & \\ \text { O.O. } & 0.3 & 0.3 & 0.1 & 0 & 0 & 0 & & \\ \text { P.O. } & 1.1 & 0.7 & 0.4 & 0.3 & 0.5 & 0.4 & \\ \text { I.U. } & 2.2 & 1.2 & 0.9 & 0.7 & 0.7 & & \\ \text { Avge. } & 1.6 & 1.4 & 1.1 & 0.95 & 1.0 & & \end{array}$

\begin{tabular}{|c|c|}
\hline $\begin{array}{r}\text { Morph } \\
\text { Mon } \\
\text { reduc }\end{array}$ & $\begin{array}{l}\text { of Bacilli } \\
\text { ken for } \\
\text { normal } \\
\text { by: }\end{array}$ \\
\hline $50 \%$ & $100 \%$ \\
\hline$<1$ & $7^{20}$ \\
\hline 1 & 6 \\
\hline$<1$ & 4 \\
\hline 2 & 6 \\
\hline 2 & 3 \\
\hline 2 & 5 \\
\hline 2 & 5 \\
\hline 2 & 3 \\
\hline 1 & $\begin{array}{r}>5 \text { persisting } \\
\text { (nose only) }\end{array}$ \\
\hline 1 & $\begin{array}{r}>4 \text { persisting } \\
\text { (nose only) }\end{array}$ \\
\hline
\end{tabular}

Where Bacterial Index is concerned, previous experience with Etisul alone was reproduced here, with a very marked reduction in Bacterial Index during the first two months which was greatly in 
excess of the DDS standard. During the third and fourth month slowing down of progress was again evident, and it is clear that the combination of DDS with Etisul did not succeed in obliterating this phase. In those whose period of observation has extended beyond this time, progress has been resumed, and has been very satisfactory.

The action of the combined treatment on the morphology of bacilli is very striking. Within 1 month, in 5 out of 10 cases, the proportion of normal bacilli in routine smears had fallen by $50 \%$, and in the entire group this point was reached within two months. Even more remarkable is the fact that within the short period of this trial normally staining bacilli have entirely disappeared from all skin sites examined, though in one case they linger in the nose.

\section{Group (b) Short course of DDS preceding combined treatment with Etisul}

In this group of 14 patients, 7 had had no previous chemotherapy when they first consulted us. These were given $100 \mathrm{mg}$. DDS twice weekly, raised then to $200 \mathrm{mg}$. twice weekly, and Etisul treatment introduced at this point. This meant that the maintenance dose of $300-400 \mathrm{mg}$. DDS twice weekly was attained within the first two months of Etisul treatment. The remaining 7 patients had all had short periods of DDS therapy lasting from 3-12 months either privately or at an out-patient clinic, and were admitted to the trial because of the obvious activity of their disease. Details of their bacteriological progress are given in Table 3.

\section{TABLE 3}

\section{Bacteriological status of patients receiving a short course of DDS} before starting combined treatment with Etisul

\begin{tabular}{|c|c|c|c|c|}
\hline & during $\mathrm{B}$ & $\begin{array}{l}\text { acterial I } \\
\text { ombined }\end{array}$ & $\begin{array}{l}\text { Index } \\
\text { reatment }\end{array}$ & \\
\hline & $0 \quad 1$ & 23 & $\begin{array}{lll}4 & 5 & 6\end{array}$ & 9 \\
\hline P.O.* & 2.02 .2 & 1.11 .05 & $\begin{array}{lll}1.1 & 1.6 & 1.6\end{array}$ & 1.2 \\
\hline G.N.* & 2.32 .1 & 1.31 .2 & 1.41 .52 .1 & 1.5 \\
\hline J.U. & 3.83 .3 & 3.03 .0 & $\begin{array}{lll}2.6 & 2.5 & 2.2\end{array}$ & \\
\hline O.O. & 1.30 .9 & $\begin{array}{lll}0.8 & 0.7\end{array}$ & $\begin{array}{llll}0.5 & 0.2 & 0.1\end{array}$ & \\
\hline A.I. & 1.61 .1 & 0.60 .6 & 0.80 .6 & \\
\hline M.O. & 2.72 .3 & 2.32 .2 & $\begin{array}{ll}1.9 & 1.9\end{array}$ & \\
\hline I.U. & $\begin{array}{lll}0.8 & 0.4\end{array}$ & 0.10 .2 & $\begin{array}{ll}0 & 0\end{array}$ & \\
\hline S.I. & 1.51 .4 & 1.41 .0 & $\begin{array}{ll}1.0 & 0.7\end{array}$ & \\
\hline A.A. & 2.11 .9 & 1.11 .0 & 1.0 & \\
\hline E.S. & 3.23 .3 & 3.32 .9 & 2.4 & \\
\hline O.O. & 2.01 .8 & $\begin{array}{lll}0.9 & 0.9\end{array}$ & & \\
\hline & $\begin{array}{lll}0.6 & 0.7\end{array}$ & $\begin{array}{lll}0.7 & 0.5\end{array}$ & & \\
\hline & 1.61 .6 & 1.20 .8 & & \\
\hline & 0.10 .1 & $\begin{array}{ll}0 & 0\end{array}$ & & \\
\hline
\end{tabular}

\begin{tabular}{|c|}
\hline $\begin{array}{l}\text { Previous } \\
\text { DDS } \\
\text { treatment } \\
\text { in months }\end{array}$ \\
\hline 1 \\
\hline 1 \\
\hline 10 \\
\hline 12 \\
\hline 6 \\
\hline 3 \\
\hline 1 \\
\hline 7 \\
\hline 3 \\
\hline 5 \\
\hline 1 \\
\hline 1 \\
\hline 1 \\
\hline
\end{tabular}

\begin{tabular}{|c|c|}
\hline \multicolumn{2}{|c|}{$\begin{array}{l}\text { Morphology of Bacilli } \\
\text { Months taken for } \\
\text { reduction in } \\
\text { normal bacilli by }\end{array}$} \\
\hline $50 \%$ & $100 \%$ \\
\hline $1 \frac{1}{2}$ & 6 \\
\hline 2 & 6 \\
\hline 1 & 5 \\
\hline 1 & 2 \\
\hline 0 & 0 \\
\hline 2 & 5 \\
\hline 3 & 3 \\
\hline 0 & 0 \\
\hline 3 & $\begin{array}{l}>5 \text { persisting } \\
\text { (nose only) }\end{array}$ \\
\hline 1 & 5 \\
\hline I & 2 \\
\hline 1 & 3 \\
\hline 2 & 3 \\
\hline 2 & 2 \\
\hline
\end{tabular}

* Etisul for first 3 months only.

Average ( 4 months combined treatment).

$\begin{array}{lllll}2.2 & 1.9 & 1.5 & 1.4 & 1.3\end{array}$ 
In this group also progress during the first two months was very satisfactory, and though some slowing down in the decline of Bacterial Index then occurred, there was no real check to its continued fall. Nothing was lost in these patients by giving them a few weeks course of DDS before starting Etisul, and coming months will show whether there was in fact an advantage.

The position of those who had longer periods of DDS treatment is interesting. Four of them had considerable numbers of normally staining bacilli in their smears in spite of several months of DDS treatment. In them all rapid improvement both clinical and bacteriological followed the administration of combined treatment.

In neither group have any signs yet appeared suggestive of drug resistance. The proportion of normal bacilli in routine smears has fallen continuously and regularly, not only during the first three months, but after that period in patients who have continued taking the drugs together.

\section{Etisul in combination with DDS and Ciba 1906 (DPT).}

With Etisul falling off in effectiveness at about the third month, and DDS requiring 3 months or thereabouts for the attainment of its maintenance dose, it appeared to be worth while experimenting with the use of Ciba 1906 in conjunction with the other two, for its speedy action would bring it into effect during the third month when neither of the other two may be at optimum efficiency.

Fifteen lepromatous cases, some of them severe, are taking part in this most recent part of the trial. None had had any previous chemotherapy. They received full doses of Ciba 1906 from the start, (2.0 gms. daily), 6 ccs. Etısul twice weekly, and DDS was built up on a twice weekly basis following the usual routine. 13 of the patients have now completed 3 months of this routine, 10 of them four months or longer. One additional patient developed sulphone dermatitis, and had to be withdrawn.

In all cases clinical progress has been most satisfactory, and free from any complications other than the case of sulphone dermatitis. Biopsies repeated in 4 patients have all shown substantial histological evidence of resolution. Bacteriological progress is indicated by Table 4.

These results are eminently satisfactory. In all 15 cases there was a very speedy action on the bacilli, a $50 \%$ decline in normally staining bacilli in routine smears taking place within one month in 11 of the 15 patients, while by the end of the fourth month they had disappeared from all sites other than the nose in every patient observed for this length of time, granular bacilli and debris alone being encountered. This was a new phenomenon in our experience in such advanced cases as the second and third in Table 4, both of them diffuse lepromatous cases in whom lepromatous infiltration was 


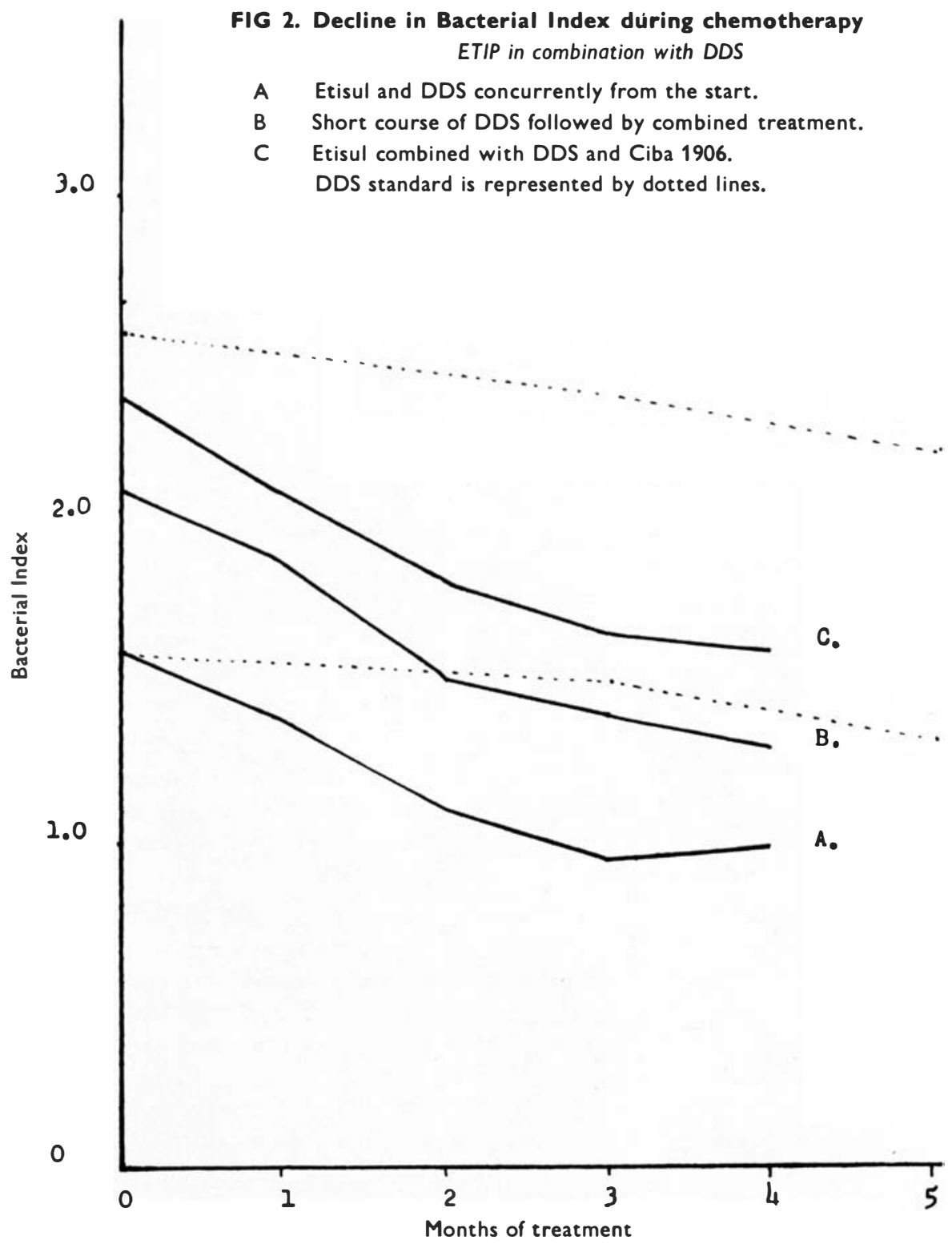

FIG. 2 


\section{TABLE: 4}

\section{Bacteriological status of patients receiving Etisul combined with Ciba 1906 and DDS}

\begin{tabular}{|c|c|c|c|c|c|c|}
\hline & \multicolumn{6}{|c|}{ Bacterial Index-Months } \\
\hline $\begin{array}{l}\text { G.E. } \\
\text { N. } \\
\text { R. }\end{array}$ & $\begin{array}{c}0 \\
1.5 \\
3.9 \\
4.0\end{array}$ & $\begin{array}{c}1 \\
1.3 \\
3.2 \\
3.8\end{array}$ & $\begin{array}{c}2 \\
0.7 \\
2.9 \\
3.6\end{array}$ & $\begin{array}{c}3 \\
0.5 \\
2.5 \\
3.0\end{array}$ & $\begin{array}{c}4 \\
0.4 \\
3.0 \\
3.3\end{array}$ & $\begin{array}{c}5 \\
0.2 \\
2.8 \\
3.0\end{array}$ \\
\hline $\begin{array}{l}\text { A.E. } \\
\text { N.O. }\end{array}$ & $\begin{array}{l}1.3 \\
3.9\end{array}$ & $\begin{array}{l}0.9 \\
3.6\end{array}$ & $\begin{array}{l}0.7 \\
3.0\end{array}$ & $\begin{array}{l}0.3 \\
3.3\end{array}$ & $\begin{array}{l}0.3 \\
3.3\end{array}$ & \\
\hline $\begin{array}{l}\text { C.O. } \\
\text { A.N. } \\
\text { S.N. }\end{array}$ & $\begin{array}{l}2.5 \\
0.5 \\
3.1\end{array}$ & $\begin{array}{l}2.3 \\
0.4 \\
2.4\end{array}$ & $\begin{array}{l}2.0 \\
0.1 \\
2.2\end{array}$ & $\begin{array}{c}2.1 \\
0 \\
2.1\end{array}$ & $\begin{array}{c}1.4 \\
0 \\
2.2\end{array}$ & \\
\hline $\begin{array}{l}\text { A.E. } \\
\text { J. } \\
\text { N.I. } \\
\text { E.A. } \\
\text { M. } \\
\text { V.I. } \\
\text { M. }\end{array}$ & $\begin{array}{l}0.6 \\
2.6 \\
1.7 \\
0.6 \\
3.2 \\
4.0 \\
0.25\end{array}$ & $\begin{array}{l}0.5 \\
2.4 \\
0.9 \\
0.7 \\
3.1 \\
3.7 \\
0.1\end{array}$ & $\begin{array}{l}0.4 \\
2.5 \\
0.8 \\
0.7 \\
3.1\end{array}$ & $\begin{array}{l}0.4 \\
2.2 \\
0.7 \\
0.4 \\
2.6\end{array}$ & $\begin{array}{l}0.2 \\
1.8\end{array}$ & \\
\hline
\end{tabular}

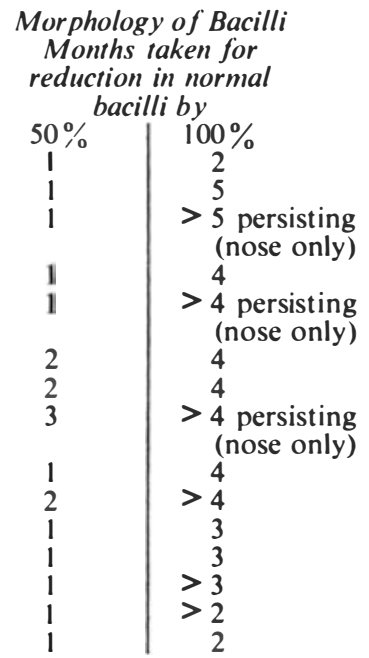

Average (patients completing 4 months treatment). $\begin{array}{lllll}2.4 & 2.1 & 1.8 & 1.65 & 1.6\end{array}$

encountered through the whole thickness of the corium in biopsy material. In this group the decline in Bacterial Index was also notable, though once again some diminution in the rate of progress can be detected between the third and fifth months in some patients.

In Figure 2, the variation in Bacterial Index during the period of observation is shown for the three groups of patients receiving combined treatment.

In Table 5 the change in bacterial morphology in the various groups is compared with that experienced with Ciba 1906. In all groups receiving Etisul it will be noticed that the proportion of normally staining bacilli in routine smears declined more rapidly than in the case of Ciba 1906, and was most marked in the group receiving Etisul in combination with Ciba 1906 and DDS.

\section{Discussion}

During the past six months numbers participating in this trial have doubled, and evidence has continued to accumulate that in Etisul we have a drug with a limited but very valuable sphere of action.

Toxicity presents no problems. Careful laboratory control has been exercised in all the 133 patients who have received courses of Etisul, and no toxic action of any kind could be detected. The problem of administration has largely disappeared as patients have 
TABLE 5

Speed of change in staining properties of M. leprae during chemotherapy

\begin{tabular}{|c|c|c|c|c|c|c|c|c|}
\hline \multirow{2}{*}{$\frac{\text { Assessment }}{\text { Drug }}$} & \multicolumn{4}{|c|}{$\begin{array}{l}\text { Decline by } 50 \% \text { in proportion of } \\
\text { normally staining bacilli in smears }\end{array}$} & \multicolumn{4}{|c|}{$\begin{array}{l}\text { Decline by } 100 \% \text {, Bearing } \\
\text { granular bacilli and debris only }\end{array}$} \\
\hline & $\begin{array}{l}\text { Ciba } \\
1906\end{array}$ & $\begin{array}{c}\text { Etisul for } \\
10-12 \\
\text { weeks followed } \\
\text { by } D D S\end{array}$ & $\begin{array}{l}\text { Etisul in } \\
\text { combina- } \\
\text { tion with } \\
\text { DDS }\end{array}$ & $\begin{array}{c}\text { Etisul } \\
\text { combined } \\
\text { with DDS and } \\
\text { Ciba } 1906\end{array}$ & $\begin{array}{l}\text { Ciba } \\
1906\end{array}$ & $\begin{array}{c}\text { Erisul for } \\
10-12 \\
\text { weeks followed } \\
\text { by } D D S\end{array}$ & $\begin{array}{l}\text { Etisul in } \\
\text { combina- } \\
\text { tion with } \\
\text { DDS }\end{array}$ & $\begin{array}{c}\text { Etisul } \\
\text { combined } \\
\text { with DDS and } \\
\text { Ciba } 1906\end{array}$ \\
\hline No. of patients & 17 & 19 & $22^{*}$ & 15 & 17 & 19 & $22^{*}$ & 15 \\
\hline $\begin{array}{l}\text { Time } \\
\text { Up to } 1 \text { month } \\
2 \text { months } \\
3 \text { months } \\
4 \text { months } \\
5 \text { months } \\
\text { Over } 5 \text { months } \\
\text { Uncertain** }\end{array}$ & $\begin{array}{l}1 \\
7 \\
6 \\
3 \\
- \\
-\end{array}$ & $\begin{array}{r}4 \\
11 \\
1 \\
1 \\
1 \\
1 \\
-\end{array}$ & $\begin{array}{r}10 \\
10 \\
2 \\
- \\
- \\
-\end{array}$ & $\begin{array}{r}11 \\
3 \\
1 \\
- \\
- \\
-\end{array}$ & $\begin{array}{r}-1 \\
1 \\
1 \\
2 \\
12 \\
-\end{array}$ & $\begin{array}{r}2 \\
3 \\
2 \\
1 \\
11 \\
-\end{array}$ & $\begin{array}{l}-3 \\
4 \\
2 \\
3 \\
9 \\
1\end{array}$ & $\begin{array}{l}-2 \\
2 \\
4 \\
1 \\
1 \\
5\end{array}$ \\
\hline
\end{tabular}

* Excluding 2 patients who had only granular bacilli on admission.

** Patients not yet completing 5 months treatment but still exhibiting some normally staining bacilli in routine smears, particularly in the nose. 
witnessed the effects of the drug. It has become a popular form of treatment.

The sphere of usefulness of Etisul is clearly at the onset of treatment. Its activity has two aspects. There is in the first place the shortlived but sometimes powerful chemotherapeutic action which has been observed in every group studied, and which appears to last for about two to three months, but then diminishes and may disappear altogether. In the second place there is the continued accelerated resolution which has repeatedly been witnessed during standard chemotherapy following a short course of Etisul.

The mode of action of Etisul is of great interest. The most striking effects on the bacilli have occurred in those patients in whom the bacilli have been almost or entirely $100 \%$ normal in their staining properties, regardless of the severity of the infection. The details given earlier in this paper show how speedily the situation may change in such patients. One of its interesting features is that quite regularly bacilli of normal type have been found to linger longest in the nose. These are not saprophytes, all patients concerned having unmistakable globi in nasal smears. The drug undoubtedly has a speedy action on the staining qualities of the bacillus, and for this and other reasons it has been suggested that its action may be more bacteriocidal than bacteriostatic.

The combinations of Etisul with DDS, and with DDS and Ciba 1906 together, have so far given very encouraging results. In these groups progress has been rapid and uniform, and with most of the patients now past their fourth month of combined treatment, no evidence suggestive of drug resistance has been seen as yet. In deciding whether or not to precede Etisul treatment with a short course of DDS it is well to consider the psychological stimulus provided by Etisul inunction. Most patients need this as early as possible.

One month's treatment with DDS before initiating Etisul has been found satisfactory and logical, Etisul being given when the dose of DDS has reached the therapeutic level of $400 \mathrm{mg}$. weekly. Although Etisul has been continued in these groups beyond the third month, further study will be needed before it can be determined whether this is therapeutically desirable or not. The good long term results in those patients who had short courses of Etisul suggest that long courses may be unnecessary. It would be logical to continue Etisul until bacilli of normal appearance can no longer be found in routine smears, and two short courses separated by an interval may be preferable to one long course. These matters call for further study.

In conclusion it may be said that further experience has confirmed earlier impressions of the usefulness of Etisul, but the work here reported remains essentially a pilot trial of exploratory nature. The large scale trial of the drug along the lines here suggested is now called for. 


\section{Summary}

A further stage in the pilot trial of Etisul in leprosy treatment is reported. Earlier impressions are confirmed that this drug lacks toxicity and is of value in the early stages of treatment, inducing a rapid change in the staining properties of the bacilli, and a rapid fall in the Bacterial Index, and leading to accelerated resolution.

It has been found to combine readily with DDS, and with Ciba 1906 in addition. When combined in this way resolution has been rapid and uniform, and after four months no sign of drug resistance has been detected.

Large scale trials are now called for.

\section{Acknowledgements}

Grateful thanks are due to Dr. L. Hogerzeil, Area Superintendent, Uzuakoli Settlement, whose co-operation in other responsibilities has enabled undivided attention to be given to this work. Thanks are also due to $\mathrm{Mr}$. S. O’Neill, Laboratory Superintendent, Mr. S. Oshinloye, Technician, and Mr. I. Mba, Clinic Assistant.

Thanks are due to Imperial Chemical Industries Ltd., Pharmaceuticals Division, for continued generous supplies of Etisul, and particularly to Dr. .J M. Mungavin for advice and encouragement, and also to Dr. R. J. W. Rees, of the National Institute of Medical Research, London, for valuable suggestions and advice.

Thanks are also due to the Permanent Secretary, Ministry of Health, Eastern Region, Nigeria, the Director of Medical Services, Dr. S. E. Onwu, c.v.O., and the Rural Health Officer, Dr. K. S. Seal, for permission to publish.

\section{Reference}

Davey, T. F. and Hogerzeil, L. (1959) Leprosy Review XXX, 61. 